\title{
THE CONTRIBUTION TO MEDICAL WORK AND NURSING BY THE PIONEER MISSIONARIES OF THE D.R.C. MISSION IN NYASALAND (MALAWI) FROM 1889-1900
}

\author{
J Smit
}

\begin{abstract}
Summary
Although the first, pioneer missionaries of the D.R.C. Mission were not fully qualified medical doctors, they played a big role in introducing western medicine among the indigenous population and in this way countered the practice of the witch-doctors.

With their limited knowledge of medicine, they knew enough to treat the indigenous people, their fellow missionaries as well as other people like government officials, planters and hunters in the central province, where they were stationed. They managed to save lives and started with health education to motivate the people to think and live more hygienic lives and thus uplift the standard of health of the country.

One can not but have admiration for their courageous perseverance and faith
\end{abstract}

and the skilful way in which they applied their medical knowledge in the absence of a fully qualified medical doctor.

\section{Opsomming}

Die eerste sendeling van die N.G. Kerk, Ds. A.C. Murray, het op 28 Julie 1988 in Nyasaland (Malawi) aangekom. Hy het in die begin eers saam met die Skotse sendelinge van die Vrye Kerk van Skotland te Livingstonia, in die noorde van die land, gewerk. Daarna het die N.G. Kerk in 1889 hul eie sendingstasie te Mvera in die Sentraal Provinsie van die land gestig.

Anders as die Skotse sendelinge het die N.G. Kerk Sending vir die eerste elf jaar nie 'n gekwalifiseerde geneesheer gehad nie. Gedurende hierdie periode het die predikante eers in kort mediese kursus van 18 maande tot twee jaar in Londen of Edinburgh gevolg voordat hul na Nyasaland gegaan het. Mediese werk is gesien as deel van die doel om 'n Christelike lewenswyse aan die mense te bring.

Die predikante het hul nooit as ware mediese dokters gesien nie, omdat hul met soveel ernstige siek pasiënte te doen gekry het, wat hul nie kon behandel nie. Hul het dus gedurig aan die N.G. Kerk in Suid-Afrika pleidooie gelewer vir 'n gekwallfiseerde mediese dokter.

Ten spyte van hul tekortkominge het hul wel 'n goeie mediese diens aan die inheemse mense van die land gelewer. $H u l$ het ' $n$ belangrike bydrae gelewer in die bekendstelling van westerse medisyne aan die bevolking en op die wyse die praktyk van die toordokters teengewerk en sodoende 'n nuwe lewenswyse aan die mense gebring.

\section{Introduction}

This abstract forms part of a $\mathbf{M}$. thesis in nursing named "The role of the Dutch Reformed Church Mission in the development of nursing in Nyasaland (Malawi) from 1860 to 1927", with studyleaders Prof. I.M. Hofmeyr and Prof. D.J. Kotze.

Unlike the Scottish Mission, the D.R.C. Mission did not have a fully qualified medical doctor for the first 11 years. When seriously ill or for confinements they were dependent on the services of the Scottish mission doctors, a five day journey from Mvera, their first mission station. During this period, the first ordained missionaries of the D.R.C. Mission, followed a short medical course to equip themselves for the medical aspect of the work. They had a limited knowledge of medicine but nevertheless they rendered a wonderful medical service to the indigenous people of the country. They introduced western medicine among the indigenous population and thereby countered the practice of the witch-doctors and introduce a new mode of living to the people.

The motive for medical work and the medical training they followed will be described shortly. Their contribution to medical work and nursing towards the indigenous people, their fellowmissionaries and their services to other people will be discussed. The ordained missionaries never saw themselves is true medical doctors and pleased constantly for their own medical doctor.

\section{The motive for medical work}

The first missionaries of the Dutch Reformed Church Mission who went to Nyasaland, were called medical missionaries. They were ordained ministers of religion but also followed a short course in medical work to prepare themselves for the medical aspect of the work. Medical work was included in missionary work because God commanded it in the Scripture. Their medical skill was used to draw the people to God. It served as a means to convey to the people the message of Christ's compassion. From the beginning of the very first mission station at Mvera in 1889, a rule was made that all people who wanted medicine, had to attend morning prayers first. ${ }^{1}$

According to Bosch, medical work was traditionally pointed to in the early mission literature as an 'auxilliary-service'.2 That may account for the reason why the early medical missionaries often saw medical work as a side-issue, a means to an end, to win the affection of the people. ${ }^{3}$

In his first book, (Nyasaland en mijne ondervindingen aldaar, 1897, p. 218) A.C. Murray then also described such a case. While on a journey in an unknown region he was received as a friend by the people of a certain village, while at the other villages the people were suspicious and frightened.
He then later discovered the reason. A girl, whom he had treated at Mvera for a long period for an ugly ulcer on her foot, stayed in that particular village. She thus prepared the heart of her people for them.

He treated 200 patients who made 600 visits during four and a half months at Mvera. This medical care must have take. up a considerable part of his day, as he dressed all the numerous ulcers himself. $\mathrm{He}$ also mentioned in the same report that it was unfortunately impossible to visit all of the patients at home because of an overload of work. ${ }^{4}$ In April, 1890 he reported that sometimes 20 patients would come per day. 5

A.C. Murray also stated in his book, ${ }^{6}$ that he did not have much to tell about medical work as he never considered it an important part of his work, but only as a side-issue. In contradiction to this statement he regularly reported on the medical work done and even named the different diseases he treated.

The missionaries never saw themselves as true medical doctors and were many times made conscious of their lack of knowledge and the gap in their medical training when confronted with a patient with a serious illness, often a fellowmissionary. In spite of their constant appeals for a fully qualified medical doctor, the mission had to wait eleven years before the first medical doctor arrived. 
In spite of their shortcomings they rendered a wonderful medical service to the indigenous people of the country, their fellow-missionaries, and other Europeans in the country.

\section{Medical training}

The first missionary of the Dutch

Reformed Church Mission, A.C. Murray, went to Edinburgh, Scotland, for 18 months to study medicine. He was followed by Rev. W.H. Murray in $1894 .^{7}$ Unfortunately they never recorded any of their experiences while studying medicine in Edinburgh.

When reading through their medical reports, letters, inscriptions in their diaries and tales in the books written by them, it is obvious that the two men knew a good deal about medicine. The daughter of W.H. Murray, Dr. Pauline Pretorius, now retired at Stellenbosch after a life-time's work in Nyasaland, could give the

earcher more details about her father. ney knew how to diagnose and treat tropical diseases like malaria, blackwater fever and tropical ulcers. They could stitch wounds and drain abscesses. They had knowledge of the administration of chloroform, the dispensing of medicine and knew how to conduct a delivery. W.H. Murray even treated gynaecological cases like menorrhagia and medical cases, such as pneumonia, heart disease and tuberculosis. They could extract teeth, and were equipped with the necessary instruments.

The medical course they followed must have been quite an advanced course, possibly the same lectures as the medical students, as A.C. Murray discovered that Dr. Grant, a gun-boat doctor, who came to his help after he was attacked by a leopard, attended classes with him in Edinburgh during 1887. According to him they sat in the same medical class, only did not know it.

The missionaries who came after these two - A.L. Hofmeyr (1900), A.G. Murray (1900), J.A. Retief (1908) and P.A. Rens (1911) - went to Livingstone College, London. Details about the college and the medical course was found in an article in De Koningsbode 1905, September, p. 96.

The College was founded during 1893 by a mission doctor, Dr. C.F. Harford.

During this medical course, lectures in medical work were given in the College and practical work was done at several hospitals, in the treatment of wounds (ulcers) and the setting and splinting of fractures, nursing seamen with tropical diseases, the dispensing of medicine, how to diagnose and treat eye and skin diseases. They had the opportunity not only to nurse the patients, but to bring the gospel to them.

Although the mission acquired its first medical doctor during 1900, it was impossible for him to render medical care to all the people falling under the jurisdiction of the mission. The medical doctor was only called for serious illnesses when the ordained missionaries could not cope.

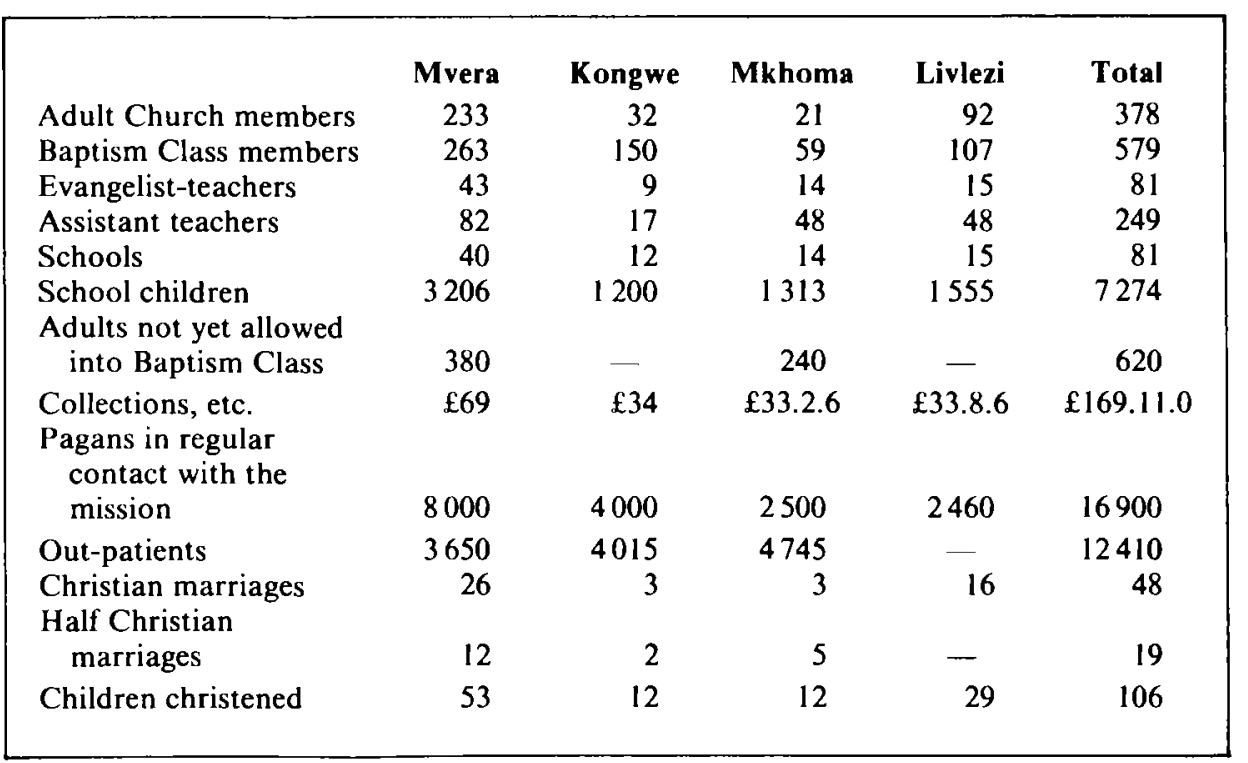

Their task towards the indigenous people

When A.C. Murray arrived at Bandawe, Nyasaland, on 28 July 1888 , he had not yet mastered the Nyanja language and therefore was unable to help the Scottish missionaries in preaching the gospel. He could, however, help Dr. Laws with medical work. Thus from the beginning of his missionary career, he could use his medical expertise, which he regarded as a side-issue, and by it, spread the gospel through his deeds. Medical work is seen as the expression of the total message of Jesus Christ, according to Luke 9:2.

At Bandawe he immediately started to help Dr. Laws vaccinating the people against smallpox. He mentioned in his travel journal, ${ }^{9}$ that the people were as frightened of the vaccination as of the smallpox. Still they came as they noticed that the missionaries' medicine helped them to survive. A shoemaker's awl was used for making the scratches on the arm, and then the serum was rubbed in. ${ }^{10}$

While staying with Mr. Bain and Dr. Cross at the village of chief Kararamuka, when looking for a mission station, Murray described several incidents where he administered medicine to the villagers. On one occasion he was able to give Dr. Cross some medicine for the Chief who was suffering from sore eyes. $" 1 \mathrm{He}$ mentioned another case where a woman brought her child, with two ulcers on the abdomen, and presented a fowl as a present. Murray dressed the ulcers with carbolic oil and gave the mother a little spare carbolic oil and " . . bandaged the child with calico to the value of the fowl'. 12 Medicine was free but the people paid homage to the missionary with presents such as chickens, maize or eggs.

The medical missionaries were pioneers in introducing western medicine among the indigenous population and in this way countered the practice of the witchdoctors. They met with many problems. At first the local people had prejudices against the missionary and his medicines. They had their own doctors, and naturally, only went for medical care to the missionary after they had tried all their local remedies.
The patients who came to them in the beginning were often suffering from advanced diseases which could not be cured by their local medicine man. Murray diagnosed the following diseases while at Mvera, and described them as serious: dysentery, bilious fever, pleurisy, epilepsy, leprosy where the toes and fingers were beginning to fall off and with skin discolour, pulmonary tuberculosis and cardiac disease. These were all diseases for which he himself could do very little. ${ }^{13}$ An old woman even requested him to remove a cataract from her eye, which, as he stated '... neither the old woman nor I dare venture, though for different reasons'. ${ }^{4}$

On the other hand, the Scottish missionaries at Livingstonia in the north and Blantyre in the south of Nyasaland, as well as the missionaries of the Universities' Mission to Central Africa at Likoma Island, had established medical practices at the time when the missionaries of the Dutch Reformed Church Mission arrived. The indigenous people had by then, if not treated by them, most probably heard about the white man's medicines. Murray explained in his book ${ }^{15}$ that the people regarded them as such wonderful people, that no disease was too great for them to cure, indeed, they were expected to do so with the greatest ease.

While still staying in their tents at Mvera, and while building their house, Murray reported: 'A fair number of patients came for medicine, as however my medicines are mostly still packed in boxes there being no room to put them out, I cannot do so much as I should wish.'16

As they believed that disease was the result of spirit or mystic influences and in the power of witchcraft, they expected to be cured by the 'witchcraft' of the white man. On one occasion an old chief came to ask Murray for medicine for his rifle, as he had an old rifle and he was unsuccessful when hunting. ${ }^{17}$

Their belief in the power of witchcraft sometimes led them to accuse the missionaries of killing the people. Murray and Vlok related such cases. 'Old

Tshidomai died suddenly. On the following 
day I went to his funeral but was somewhat coldly received and soon told by the Chief that 1 must go, so I left and heard them firing many shots immediately afterwards over his grave. The Angoni were afraid of me, some hid, and they were all suspicious. It seems that months ago I told old Tshidomai that we must all die and this has been continued into a prophesy that he would die within two years. ${ }^{18}$ On 18 December Vlok made the following inscription in his diary, 'Accusations against us. It is said that we have killed the woman that we tried to save after the birth of her child, also that we have said that Tshidomai could live only two years longer." 19

Every village had its own midwives, and in the beginning the missionaries were apparently never called for deliveries. The only maternity case recorded by Rev. Vlok, was a primipara with obstructed labour. Early on the Sunday morning, 14 December 1890, A.C. Murray was called to a nearby village to assist a young girl of $17-18$ years. She was well-known to them as she often helped with brickmaking. She had been in labour since the Friday. Although Murray spent the most of the day with the girl, only leaving her to conduct the Sunday morning service, he did not succeed in delivering the baby. After lunch, Vlok assisted him to administer chloroform but he was still unable to remove the baby. Eventually he succeeded early on Monday morning in removing the macerated foetus. The mother, who was very weak and exhausted by then, died during the afternoon. Vlok managed to convey their helplessness and empathy with this sentence, 'God alone knows how sore my heart is and what deep sympathy I felt with the mother on whose lap she died, yea with her brothers and sisters she has parted with.' This tragedy again gripped their hearts revealing the plight of the people and strengthened their missionary calling. Vlok continued to say: 'Oh! God! Help us to be more faithful in preaching the Gospel of Christ. ${ }^{20}$

Mentally disturbed people were also brought to Murray for help, but unfortunately it lay outside his power to cure them. One man was brought to him, with the string that he had been tied with, still around his legs. The other man was tied naked to a tree with a heavy slave yoke over his neck. He had been sitting like that for the past four years. ${ }^{21}$

He realised the need of a qualified medical doctor, and in the report to the Minister's Mission Union, 1 September 1890 , he wrote that he trusted that they would soon be able to send a qualified doctor to the Mission. ${ }^{22}$

There were, however, many diseases he could treat. During cold weather many patients would come with '... cold on the chest,' and '.. the stomach also, here as elsewhere, is a fruitful source of trouble'. ${ }^{23}$ Many patients came with ulcers to be dressed and teeth to be extracted. Murray stated that he was happy to report that they could do more for the patients than only relieving their suffering. ${ }^{24}$

People were frequently injured by wild animals like lions, crocodiles, leopards, elephants, snakes, bush pig and even goats. Murray reported a particular case where one of the councillors of chief

Nsakambewa, who ruled over the northern part of Chiwere's country, urgently begged them to come to help them. There was much sickness in their district and many were dying, also the lions and leopards were troubling them. They wanted 'medicine' against these wild animals, as one of their chiefs was killed and a woman had been carried off by a lion while working in her garden. The people were now afraid to go to their gardens. Murray promised to go later one day to kill the wild animals. ${ }^{25}$

Accidents and violence occurred regularly. In a letter from Livlezi, Vlok described a case of an old woman they had tried to kill with an axe. 'She had 13 awful cuts in the neck and shoulders. It is marvellous that she is living and I am glad to say the wounds are healing beautifully. ${ }^{26}$

Vlok also recorded in his diary several accident cases that were miraculously healed by his medical treatment. "A child was brought to the station, one eye having been stuck out by a stick. The child underwent medical treatment till the eye was healed, though he had lost the power of seeing. ${ }^{27}$

The early missionaries not only treated people on their mission station but when they went from village to village preaching the gospel, they treated the sick to the best of their knowledge. ${ }^{28}$

The missionaries had limited stocks of medicine and their resources were slight as their financial income was small. These factors made it difficult for them to treat diseases properly. Murray diagnosed two cases of cardiac disease but did not have digitalis to treat it. ${ }^{29}$

Another factor which the missionaries had to take into account, was the ignorance of the people of western medicine. Health education was thus very important as it could be dangerous to give patients medicines to take home, as a patient might most probably take all of it at once to get well quicker. A mother or a father might drink the medicine instead of a sick child. They might even drink liniments. Murray described a case where a man with severe abdominal pain was brought to him by Chief Chiwere. The man was apparently in such agony because of the medicine he received from Murray - it might have been liniment! He then gave the patient an emetic, with success. ${ }^{30}$

Murray made friends with the indigenous doctors and told about a witchdoctor, Mchukuru, who lived one hour's walk from Mvera.

Murray described some of the local medicines used by the indigenous doctors. ${ }^{31}$ The missionaries played an important part in fighting the poison ordeal of the witch-doctors. Interesting details about the missionaries part can be read in the following books:

Murray, A.C., 1897, Nyasaland en mijne ondervindingen aldaar, Amsterdam, pp. 171-175; Murray, A.C., 1931, Ons Nyasa
Akker, Stellenbosch, pp. 47-48; Murray, W.H., 1940, Op Pad, Cape Town, pp. 103113; Retief, M.W., 1948, Verowerings vir Christus, Stellenbosch, pp. 28-29; 60-63.

\section{Their task towards their}

\section{fellow-missionaries}

The first missionaries ran great risks in offering their services to the mission as they could contract the tropical diseases endemic to the country. The risk was possibly the greatest during the decade 1890 to 1900 although they knew by 1898 that the mosquito carried the fever to man. They urged that every adult person should take 5 grains of quinine once a day as a prophylactic. The missionaries had continued attacks of malaria and blackwater fever in spite of the quinine they took prophylactically. For the period 1889 to 1900, out of 19 missionaries of the D.R.C. Mission in Nyasaland, three died from blackwater fever and several others had to leave the country for health reasons.

During their travels they later discoverci that the low lying parts of the country, especially near Lake Nyasa, were more unhealthy than the higher regions. Murray reported in 1890, after a ten year stay at Mvera, that he and Vlok had less malarial attacks, his last attack being one year ago. He subsequently discovered that as soon as he visited the lake, especially Kota Kota, he again had severe fever. ${ }^{32}$

Mvera then was a fairly healthy station but Livlezi was known as an unhealthy station as three Scottish missionaries died there, while they occupied the station. ${ }^{33}$ When the D.R.C. Mission took over the station during 1895, Rev. Vlok and his bride were stationed there. Vlok was moved to another station (Mkhoma) only after the death of his wife. She had many severe attacks of malaria, gave birth to a baby which died after birth, and she herself died a few weeks after the baby on 2 March 1896 after only a year in the country. ${ }^{34}$

Of the first 19 missionaries who came to the mission within the first decade, only two had formal training in medical work, namely Rev. A.C. Murray and his cousin Rev. W.H. Murray who arrived during 1894. Although the other missionaries had medicines in stock to treat their families and the local population on their stations, the two Murrays were called upon by their fellow-missionaries when they were seriously ill. In a letter to her family, Bessie Vlok wrote that she felt better after her husband's medical treatment and good care. ${ }^{35}$

Qualified doctors were far away, the nearest being the doctors of the Free Church of Scotland at Livingstonia, a five day journey from Mvera. The 19 D.R.C. Mission missionaries by 1899 on the three stations, Mvera, Kongwe and Mkhoma were thus dependent on the services of these Scottish doctors when seriously ill or for confinements. When A.C. Murray was mauled by a leopard on 4 January 1895 , he had to give himself emergency treatment. Although a messenger was immediately sent to call a doctor, he, his wife and 
fellow-missionaries had to wait in agony for five days before a doctor arrived.

He had several wounds and lost much blood. In a letter by Robert Blake to the Rev. Albertyn, Secretary of the Ministers' Mission Union, he described Murray's wounds as follows: 'The wounds in his head are severe, and at the back of the head a small wound closed up too soon and occasioned a large abscess under the scalp, which caused a high fever for nine days. ${ }^{36}$

In his book ${ }^{37}$ A.C. Murray described the accident and related how after the accident he had to instruct the missionaries present (seven of them were together for the New Year holidays) how to clean and stitch the wounds.

They had sent a messenger immediately to the captain of the steamboat to fetch a doctor, and he had to go to the other side of the lake to fetch one of the government gun-boat doctors, who came at once. Although he came as soon as possible, it iwas the fifth day when he arrived at era. ${ }^{8}$ Distances were great, there were no roads and he had to be carried by machila in the rain from the lake to Mvera. (A machila consisted of a hammock slung on poles in which a traveller was carried by porters.)

Dr. Grant could then stop the bleeding and open the abscess. (It turned out that he was a fellow-student of Murray while at Edinburgh.) Dr. Grant could only stay one day, as he had patients urgently waiting for him, and left instructions with Mrs.

Murray. He said that the patient was not in need of medical care but needed good nursing care. In his book, ${ }^{39}$ Murray related how grateful he was to his wife for caring for him so well, not only physically but also assisting him spiritually.

A week later another abscess started to form and then, according to Murray, the Lord sent his cousin, W.H. Murray from Livlezi, who could drain the abscess in. ${ }^{40}$ It took the messengers four days Mvera to Livlezi. W.H. Murray then stayed on to help with the nursing of his cousin, but when a week later the patient had a relapse and developed a high temperature and became so delirious that they had to tie him to his bed, they were relieved when Dr. Prentice of Livingstonia came to Mvera of his own accord. Dr. Prentice had heard about the accident and decided to come immediately. (It took three weeks for the news to reach Livingstonia through Dr. Grant.) Dr. Prentice stayed at Mvera for three weeks, taking care of Murray until he was out of danger.

Murray's health was so undermined that Dr. Prentice ordered him, his wife and baby to return to South Africa to recuperate. He was in such a poor condition that Dr. Prentice thought he would never return to Nyasaland again, but he returned in two years time. In a letter from Dr. Prentice to Rev. Andrew Murray at Wellington, he said the following: 'Mr. Murray, although much better before I left for Bandawe, was still very weak, and as you have no medical missionary in your field, I could not leave without urging the desirability of a complete change and in fact thought it necessary to invalid him home. ${ }^{42}$

This accident made a great impression on the village people at Mvera. They thought Murray was going to die, and when he came out of the house after six weeks, many people came to see him, praising the Lord and acknowledging that it was God that had healed him.

Prayer went hand in hand with medical care and the missionaries also saw the hand of God in the accident. In a letter Rev. Robert Blake wrote, 'In all things the Lord has been very good to our little band and this accident has bound us together as nothing else could have done. May our sympathy with each other extend henceforth more fully in our work. ${ }^{43}$

There were close ties of concern between the Scottish and D.R.C. missionaries. This letter of commiseration of Robert Laws to W.H. Murray also showed the spiritual bond between the two Missions. ${ }^{44}$

The confinements of their wives and those of their fellow-missionaries always produced a problem to the medical missionaries. It meant that either one of the Scottish doctors had to come to their station to conduct the delivery or the pregnant lady, usually accompanied by her husband, had to travel all the way to where the nearest Scottish doctor was stationed. This caused endless loss of time and frustration to the missionaries.

The birth of the first baby in the D.R.C. Mission, the baby of Bessie Vlok, is a tale of agony and suffering. The Vloks were stationed at Livlezi, an extremely unhealthy site. Bessie Vlok frequently suffered from malarial attacks. The baby died shortly after birth, Mrs. Vlok was in a fairly good health, but on Sunday 1 March she had a severe attack of malaria and died the following evening. ${ }^{45}$

The second midwifery case was that of the first baby of Rev. and Mrs. A.C. Murray. He and his wife were obliged to go to Ekwendeni, to Dr. Elmslie, the nearest Scottish doctor at that time. ${ }^{46}$

The couple had to wait for more than a month at Ekwendeni before their son, Charles Leonard, was born on 7 August. In a letter to Rev. Albertyn from

Ekwendeni during their residence, Murray again stressed their need for their own doctor,... we were obliged to come here and remain with Dr. Elmslie until the event is over. Oh for our own doctor!'47

With the birth of the first daughter of Rev. and Mrs. Blake of Kongwe, on 4 November 1894, Dr. Prentice of Bandawe came over for the delivery. In a letter to Rev. Albertyn, Blake commented that by this event they not only felt the need for their own doctor in their mind but also in their pockets, as they had to pay his travelling fee of $£ 13$. They were anyhow very grateful to Dr. Prentice for the sacrifice he made in leaving his practice to come to Kongwe to assist them. ${ }^{48}$

For the birth of their second daughter, the next year on 30 May 1896, the Blake couple went to Bandawe where Dr. Prentice did the delivery. They were obliged to stay two months at Bandawe as complications set in during the delivery. Dr. Prentice suggested that she should return to South Africa for medical care. 'He thinks that if she is attended to in time by a surgeon at home all the damage may yet be repaired. He could not perform the operation here under the necessary conditions for success. ${ }^{49}$

Robert Blake again brought the fact of their suffering in the absence of a qualified mission doctor, to the attention of Rev. Albertyn, Secretary of the Minister's Mission Union. 'To the Livingstonia Mission we feel indebted for medical help and are not able however to give any decent donation in aid of their work to show our thankfulness. "so

During the two year absence of A.C. Murray, 1895 - 1897, after the leopard attack, W.H. Murray was responsible for the administration of the Mission as well as the health of his fellow-missionaries. In one such letter from Dr. Prentice to W.H. Murray on Mrs. Blake, he confirmed that both he and Dr. Laws were of the opinion that Mrs. Blake be sent back for medical treatment. In the same letter Dr. Prentice confirmed the treatment that W.H. Murray gave to a patient, most probably Mrs. Blake. 'I think your treatment was quite the correct thing. If menses are frequent and copious you might leave out the iron and continue a tonic of Quinine Arsenic and Strychnine. Tincture Nuc. Iron or one of the tinctures of Cinchona should be useful. ${ }^{51}$

The Blake family left the country during November 1896. As the Blakes had not been in the country for five years, they were supposed to pay their own homeward fare. W.H. Murray therefore needed the expert advice of a medical doctor to convince the Committee of the bad health of Mrs. Blake..$^{52}$ The family again returned during 1898.53

A second blow to the Mission during this period, was the death of Rev. J.F. du Toit of blackwater fever at Mkhoma on 30 July 1898. Rev. du Toit and Vlok were stationed at Mkhoma. While Rev. Vlok was away on an evangelising trip, Rev. du Toit became ill with blackwater fever. His carpenter, James Ndapatola, sent a messenger with a letter and a urine specimen of du Toit to W.H. Murray at Mvera. Murray decided to go immediately.

The pathway led through mountains and ravines. It was a cold night and the carriers as well as Murray became very tired. The fatigued party reached Mkhoma by sunrise the next morning, Tuesday. They found Koos du Toit extremely ill, and Murray immediately administered treatment as he was taught by Dr. Prentice. He then sent messengers to call Vlok back from his journey, as well as Miss Zondagh at Mvera, the fiancée of du Toit. ${ }^{54}$

The three took turns to nurse the patient, but he died on Friday, 30 July 1898. His death was mourned by the three missionaries. Murray ended the sad story by stating that he wished that he was a fully qualified doctor and not only possessed a little medical knowledge, or rather that the Mission had its own doctor. ${ }^{55}$ 
The death of Rev. du Toit made a deep impression on the indigenous people and many turned to Christianity afterwards, with the result that during October 1897 , 21 people were baptised at Mvera. ${ }^{56}$

After the return of A.C. Murray during August 1987 W.H. Murray wrote: 'I am so thankful for God's goodness to us at Mvera during the time I was in charge, also that my fellow workers and myself, uniformly enjoyed such excellent health. $\$$ ?

The third missionary to die of

blackwater fever was Mr. Cridland on 13 March 1898 at Kongwe.

Three missionaries - Mr. van der Westhuizen, Mr. McClure and W.H. Murray - took turns to watch with the patient for a week. The three men experienced the last 15 minutes so tense, so terrible, so shocking that their nervous systems could hardly bear it any longer. ${ }^{58}$

According to W.H. Murray the deaths of the two missionaries had a devastating effect on them mentally. Their faith in God kept them sane during these difficult and trying years. ${ }^{59}$

In a report by A.C. Murray during 1899 from Mvera, he wrote six foolscap pages on the health of the workers. During that year both Miss Zondagh (after four years) and Miss Helm (after two years) had to return home, after severe attacks of blackwater fever.

\section{Their services to other people}

Until 1900 there was no doctor in the Central Province of the country, except the two ordained medical missionaries, A.C. Murray and W.H. Murray. The first doctor in the administration of British Central Africa, Dr. Sorabji Rastonyi Boyce was appointed during June 1891, and stationed at Fort Johnston. ${ }^{60}$ Thus when the European people in the country, other than the missionaries, were in need of medical care, they turned for help to the nearest source within their reach, which was usually the missionaries.

A.C. Murray made the following inscriptions in Mvera log book on 20 May 1890: 'On several occasions the Portuguese hunter who is in the country has sent asking for medicine $\ldots .61$

Some of these people preferred to be attended by the mission doctors rather than by the Government doctors, and in his book, Op Pad,62 W.H. Murray related such an experience which he had with a European who was putting up a telegraph wire. He heard that a white man had been killed by a lion. He made enquiries and met the companion of the man who told him that the injured man, Brockman, was not dead, but badly mauled by the lion. Murray attended Brockman as well as he could, and at the request of the patient, explained the way of salvation to him. The man accepted Jesus Christ as his saviour.

The man recovered and in later years he thanked Murray again 'for saving his life that day in Central Africa'. ${ }^{63}$

\section{Pleas for their own medical doctor}

Pleas for their own medical doctor echoed like a cry of distress through the correspondence and reports of these early ordained medical missionaries as well as that of their colleagues. A.C. Murray realised that his medical knowledge was not adequate and that the mission needed a qualified doctor. ${ }^{64}$

The patient number increased to such an extent that by 1899 as many as 12410 outpatients were treated at the three Mission stations, 3650 at Mvera, 4015 at Kongwe and 4745 at Mkhoma. ${ }^{65}$ The number of patients treated at Livlezi was not indicated, although in a letter ${ }^{66}$ and in his book, ${ }^{67}$ Vlok mentioned that he treated patients while stationed at Livlezi, before the station was evacuated. W.H. Murray was stationed at Livlezi in 1894, before going to Mvera. As he was trained in medicine he surely would have treated patients. ${ }^{68}$

Although the missionaries never seemed to have complained about the extra load that treating patients brought along, it must have taken up a great deal of their time. A.C. Murray only mentioned once during 1890, that he did not have time to visit all the patients because of an overload of work..$^{69}$ The following statistics will give an indication of their work load: ${ }^{70}$

The second formal request by A.C. Murray to Rev. Albertyn for a qualified doctor, was in 1894 when he was waiting at Ekwendeni for the birth of their first son. ${ }^{71}$ Although he had training in midwifery he did not feel capable of delivering the baby of his own wife nor managing the deliveries of the wives of his colleagues.

Rev. Blake of Kongwe encountered the same problems during the two confinements of his wife, when he had to turn to the Scottish doctor for assistance. He too pleaded for a doctor. ${ }^{72}$

The deaths from blackwater fever of Rev. du Toit at Mkhoma and of Mr. Cridland at Kongwe also made W.H. Murray realise that he could not cope with such seriously ill patients.

W.H. Murray made a moving call on the Ministers' Mission Union for a doctor. He wrote the following letter to Rev. Albertyn on 12 August 1897: 'Our bereavement is so fresh and our hands so full that one hardly seems to get time properly to realize our position. Just at present there is something I'm thinking may become a keenly felt want. It is the matter of a qualified medical man with a view to more young ladies coming out and the number on our staff generally increasing. I humbly think our Committee must come to definite decision to face the question of a doctor for our Mission.'

'I do not know what A.C. Murray's position in the matter is. I feel personally that should A.C. Murray's health demand an early return to the Cape I should feel very loth to continue as the only one to whom others turn for medical advice when they wish such advice, the more so as among these others there are those who feel strongly about this matter themselves. I am not in the least blaming any one for so feeling, I merely draw attention to the fact. The problem of distance will always remain a serious objection to any arrangement with the Scottish Brethren about one of their medical men. ${ }^{73}$
This letter must have made the Ministers' Mission Union realise W.H. Murray's desperation, but it still took two years before they decided to recruit a medical doctor. During 1899 the

Committee also, for the first time, compiled the necessary regulations for the Dutch Section of the Livingstonia Mission.

The regulations stated among others the following about a medical doctor:

'1. In view of the importance of having a qualified medical man to care for the health of the mission workers, and also to undertake medical mission work among the Africans, the Committee decide to make a special effort to find a suitable man and also to make provision for his salary and other expenses.'

'5. That meanwhile, until such a medical man be found, cases, under a certificate from one who has had a year's medical course, which require the attention and treatment of a medical man be sent to the nearest medical man of the Free Church of Scotland Livingstonia Mission, and that two thirds of all travelling and other expenses be paid by the mission.'

"6. That an understanding be arrived at with the Free Church Livingstonia Mission that they give as such medical assistance when required, and that they be asked to suggest some rate at which our committee contribute to their Medical Mission Funds for such assistance as we may receive from them.'

7. That where cases of urgent necessity a medical man be called in from elsewhere to one of our stations, the committee shall pay at least two-thirds of the travelling and medical expenses. ${ }^{74}$

These welcome regulations would have surely made matters in communication much easier between the two missions. It is only to be pitied that the Committee to ${ }^{2}$ eleven years to react positively to the explanations and pleas of the missionaries.

During a meeting on 13 April 1899, the Committee noted that they accepted the offer of Dr. W.A. Murray, brother of A.C. Murray, who had taken his medical degree at Edinburgh, Scotland as mission doctor. ${ }^{75}$

One can imagine the relief and expectations of A.C. Murray when he ended off his station report at Mvera for the year 1899, with this footnote:

'Required next year: One doctor, teacher, translater, ladies for Kongwe. 76

\section{BIBLIOGRAPHY}

\section{Books}

Bosch, D.J. Die teologie van die mediese sending, Umtata, n.d. De Kerkbode, 5 December, 1890. De Koningsbode, September, 1905 Murray, A.C.: Nyasaland en mijne ondervindingen aldaar, Amsterdam, 1897.

Murray, A.C.: Ons Nyasa-Akker, Stellenbosch, 1931.

Murray, W.H.: Op Pad, Cape Town, 1940. 
Retief, M.W.: Verowering vir Christus, Stellenbosch, 1948.

Retief, M.W.: William Murray of

Nyasaland, Lovedale Press, 1958.

Vlok, T.C. B.: Elf Jaren in Midden

Afrika, Cape Town, 1901

2. Archival Records

2.1 Cape Church Archives: (CCA)

Mvera $\log$ book, P3

A.C. Murray's travel journal, 1 and 2

P3 2/1

Ministers' Mission Union Minute

Book, V9 1/l

T.C.B. Vlok's diary, P24 1/1.

Files with correspondence:

S5 15/6/2/16: Correspondence with

Dr. W.H. Murray, 1895-1918.

S5 15/6/11/4: Station Reports,

Mvera: 1889-1895.

V9 2/1: Correspondence with the

Secretary of the General Mission

Committee, 1892-1907.

V9 4/1: Ministers' Mission Union

Reports (P.S.V.-verslae), 1897-1899.

2.2 Malawi National Archives: (MNA)

Report by Commissioner Johnston on the first Three Years

Administration of the Eastern

Portion of British Central Africa, 1894.

3. Personal letter from Mrs. Isobel Irvine of Kongwe, Malawi.

4. Interview with Dr. Pauline Pretorius, Stellenbosch.

\section{REFERENCES}

1. Murray, A.C., Nyasaland en mijne ondervindingen aldaar, Amsterdam, 1897, p. 189

2. Bosch, D.J., Die teologie van die mediese sending, Umtata, n.d., p. 6.

3. De Kerkbode, 1890,5 December, p. 389.

4. De Kerkbode, 1890, 5 December, p. 389.

5. Mvera log book, 1890,18 April.

6. Murray, A.C., op cit., p. 212.

7. Minute Book, V9/1/1, Cape Church Archives (CCA), 1894, 31 January.

8. Murray, A.C., op cit., p. 296.

9. A.C. Murray's travel journal, 1 and 2 P3 2/1, 1888, 28 July.

10. Murray, A.C., op cit., p. 124.

I1. A.C. Murray's travel journal, 1888, 26 Abid., 9 October.

13. A.C. Murray's journal 2, 1889, pp. 14-15; Mvera logbook, 1890, p. 11
14. A.C. Murray's journal 2, 1889, p. 15.

15. Murray, A.C., op cit., p. 212.

16. A.C. Murray's journal 2, p. 14.

17. Murray, A.C., op cit., pp. 214-215.

18. Mvera log book, 1890, 17 December.

19. T.C.B. Vlok's diary, 1890,18 December.

20. Ibid., 14-16 December.

21. De Kerkbode, 1890, 5 December, p. 389.

22. Ibid., p. 389.

23. A.C. Murray's journal 2, 1889, p. 14.

24. De Kerkbode, op cit., p. 389.

25. A.C. Murray's journal 2, 1889, p. 15.

26. File S5 15/6/2/16, CCA; Letter from Vlok to W.H. Murray, 30 August 1895.

27. Vlok's diary, 1890: Notes on Customs of the Africans of Central Africa $I$.

28. Vlok, T.C.B., Elf Jaren in Midden Afrika, Cape Town, 1901 , p. 22; A.C Murray's travel journal, 1888; 26 August, 7 September, 9 October.

29. Mvera log book, 1890,18 April.

30. Murray, A.C., 1897, op cit., p. 213-224

31. Ibid., pp. 212-218.

32. Mvera log book, 1890, p. 33.

33. File V9 4/1, CCA: Letter from Robertson to Albertyn, 30 April, 1986.

34. Mvera log book, 1896, 2 March; Murray, A.C., 1931, op. cit., pp. 92-93; Vlok, T.C.B., 1901 op. cit., pp. 87-90.

35. Vlok, 1901, op cit., p. 89.

36. File V9 2/1, CCA: Letter from Robert Blake to Albertyn, 17 January 1895.

37. Murray, A.C., 1897, op cit., pp. 292-298.

38. File V9 2/1, CCA: Letter from Robert Blake to Albertyn, 17 January 1895.

39. Murray, A.C., 1897, op cit., p. 296.

40. Ibid., p. 296.

41. Murray, W.H., 1940, op cit., pp. 52-54.

42. File V9 2/1, CCA: Letter from Dr. Prentice to Rev. Andrew Murray, 8 April, 1895.

43. File V9 2/1, CCA: Letter from Robert Blake to Albertyn, 18 January, 1895.

44. File S5 15/6/2/16, CCA: Letter from Dr. Laws to W.H. Murray, 23 April, 1895.

45. Murray, A.C., 1931, op cit., pp. 92-93.

46. A personal letter from Mrs. Elsabe Irvine, granddaughter of A.C. Murray to the researcher, 20 June 1895.

47. File V9 2/1, CCA: Letter from A.C. Murray to Albertyn, 16 July, 1894.

48. File V9 2/1, CCA: Letter from Robert Blake to Albertyn, 30 November, 1894.

49. File V9 2/1, CCA: Letter from Robert Blake to Albertyn, 30 June, 1896.

50. File V9 2/1, CCA: Letter from Robert Blake to Albertyn, 6 August, 1896.
51. File S5 $15 / 6 / 2 / 16$, CCA: Letter from Dr Prentice to W.H. Murray, 10 October, 1896.

52. File V9 2/1, CCA: Letter from Robert Blake to Albertyn, 12 October, 1896.

53. Mvera log book, 1898 , p. 47

54. Minute Book of Ministers' Mission Union, V9/1/1, CCA, 1897, p. 13.

55. A description of the nursing care administered by W.H. Murray can be read in his book, Op Pad, 1940, pp. 130-135

56. Mvera log book, 1897, p. 45

57. File V9 2/1, CCA: Letter from W.H Murray to Albertyn, 16 September, 1897.

58. Murray, W.H., 1940, op. cit., pp. 146-147.

59. Ibid., pp. 147-149.

60. Report by Commissioner Johnston of the first three years Administration of the Eastern Portion of British Central Africa, Malawi National Archives (MNA), 1894, p. 33.

61. Mvera log book, CCA, 1890 , p. 14

62. Murray, W.H., 1940, op. cit., pp. 154-158

63. Retief, M.W., 1948, op. cit., p. 138.

64. De Kerkbode, 1890, 5 December, p. 389

65. Vlok, T.C.B., 1901, op. cit., p. 65.

66. File $S 515 / 6 / 2 / 16, \mathrm{CCA}$ : Letter from Vlok to W.H. Murray, 30 August, 1895.

67. Vlok, T.C.B., 1901, op. cit., p. 22.

68. Murray, W.H., 1940, op. cit., p. 45.

69. De Kerkbode, 1890, 5 December, p. 389.

70. Vlok, T.C.B., 1901, op. cit., p. 65.

71. File V9 2/1, CCA: Letter from A.C. Murray to Albertyn, 16 July, 1894.

72. File V9 2/1, CCA: Letters from Robert Blake to Albertyn, 16 July, 1894; 30 November 1894 and 30 June, 1896.

73. File V9 2/1, CCA: Letter from W.H. Murray to Albertyn, 12 August, 1897.

74. Minute Book, V9 1/1, CCA, pp. 21-22.

75. Minute Book, V9 1/1, CCA, 13 April 1899.

76. File S5 15/6/11/4, CCA, Mvera 1899: Something about the workers.

J.J.M. Smit RN RM M Nursing Hons BA Public Admin. Senior Lecturer

Department of Nursing

University of Stellenbosch 